\title{
Clinical chemistry investigations in recumbent and healthy German Holstein cows after the fifth day in milk
}

\author{
Jim Weber ${ }^{1 *}$, Markus Zenker ${ }^{*}$, Gábor Köller ${ }^{2}$, Manfred Fürll², Markus Freick ${ }^{1,3}$ \\ ${ }^{1}$ Veterinary Practice Zettlitz, 09306 Zettlitz, Germany \\ ${ }^{2}$ Clinic for Ruminants and Swine, Faculty of Veterinary Medicine, \\ University of Leipzig, 04103 Leipzig, Germany \\ ${ }^{3}$ Faculty of Agriculture/Environment/Chemistry, HTW Dresden \\ University of Applied Sciences, 01326 Dresden, Germany \\ jim-weber@gmx.de
}

Received: December 14, 2018 Accepted: July 2, 2019

\begin{abstract}
Introduction: Recumbency is a frequent symptom occurring throughout lactation. Its cause can be related to the energy or mineral metabolism, or to trauma or infectious diseases. We compared various clinical chemistry parameters between healthy and recumbent cows and between cows with different causes of recumbency and determined if hypocalcaemia manifests in later lactation. Material and Methods: Recumbent $(n=32)$ and healthy $(n=32)$ German Holstein cows were studied. After clinical examination, a serum sample was taken to measure the concentrations of $\mathrm{Mg}, \mathrm{Ca}, \mathrm{Fe}, \mathrm{Na}, \mathrm{K}, \mathrm{P}$, $\beta$-hydroxybutyrate, total bilirubin, non-esterified fatty acids (NEFA), urea, and creatinine as well as activities of alkaline phosphatase, aspartate aminotransferase (AST), creatine kinase (CK), and $\gamma$-glutamyl transferase in recumbent cows $>5 \mathrm{~d}$ in milk and control cows matched for age, lactation number, and pregnancy stage. Results: In recumbent cows, mean serum concentrations of NEFA, bilirubin, and CK were statistically higher, while those of $\mathrm{Fe}, \mathrm{K}$, and $\mathrm{P}_{\mathrm{i}}$ were significantly lower. Parameters compared between different recumbency diagnoses showed some descriptive Fe, K, urea, and AST differences, but these were not statistically significant. Conclusion: The results show that only a limited number of parameters have diagnostic besides therapeutic value. Although of minor importance in our study, hypocalcaemia should be considered a cause of recumbency, even outside the typical risk period of parturient paresis.
\end{abstract}

Keywords: cattle, lactation, hypocalcaemia, recumbency.

\section{Introduction}

Recumbency is a common event in buiatric practice which can occur in all stages of lactation. Consequently, there is a multitude of differential diagnoses that need to be considered in the clinical examination of recumbent cows. Categorisation of affected animals into three groups, where one contains cattle with undisturbed sensorium, another animals with disturbed sensorium, and the last those with disturbed general condition may help to confine potential causes of the disease (5). The first category includes cows with musculoskeletal as well as neural disorders caused by traumatic injuries (e.g. rupture of muscles, contusions, luxations, pareses or paralyses), metabolic diseases due to regulatory disturbances or deficiencies of some minerals (e.g. hypokalaemia or hypophosphataemia), and cattle with anxiety states in terms of psychogenic immobility. Hypomagnesaemia, hypocalcaemia, ketosis or hepatic coma can cause a disturbed sensorium. Possible reasons for disturbed general health are, for instance, severe intraabdominal disorders (such as gastrointestinal perforation, generalised peritonitis, ileus or abomasal displacement/torsion, and potentially related reperfusion syndrome), toxic metritis or mastitis, and infectious or cardiovascular diseases $(5,11)$. Even if there are limited opportunities to carry out a detailed clinical examination under practical conditions, determining selected parameters in blood analysis can be of diagnostic and prognostic value, especially in recumbent cows where the symptoms are either non-specific or not clearly detectable (28). However, hypocalcaemia is the most common cause of recumbency during the periparturient period, typically occurring $12-72 \mathrm{~h}$ after calving with 
an incidence of $5 \%$ to $7.5 \%$ in multiparous cows. Cases in heifers are a negligible fraction of total recumbency cases $(14,18)$.

Therefore the goal of this study was to compare clinical chemistry findings in different cases of recumbency in German Holstein cows at $>5 \mathrm{~d}$ in milk (DIM) and thus out of the typical risk period for hypocalcaemic paresis. We investigated serum concentration of standard parameters in blood including minerals, metabolites, and enzymes to show differences between recumbent and healthy animals and between various causes of recumbency, and to examine the occurrence of hypocalcaemia outside the risk period of hypocalcaemic paresis.

\section{Material and Methods}

Farm and management. This study was conducted on a dairy farm (in the state of Saxony, Germany; latitude: $51^{\circ} 4^{\prime} \mathrm{N}$; longitude: $12^{\circ} 50^{\prime} \mathrm{E}$; altitude: $249 \mathrm{~m}$ ) with an average stock of 1,800 German Holstein cows and a mean $305-\mathrm{d}$ milk yield per cow of 10,300 kg. Cows were housed in free-stall barns with cubicles and received a need-based total mixed ration according to recommendations for energy and nutrient supply for dairy and young cattle (12). They were milked twice a day. The herd was free of brucellosis, leukosis, bovine herpesvirus 1 (BoHV-1), bovine viral diarrhoea virus (BVDV), and Mycobacterium avium ssp. paratuberculosis (Map) infections.

Study design and case definitions. During the observation period between April 27 and November 12, 2017 , all animals at $>5$ DIM presenting as recumbent dairy cows (RDC) to the herd veterinarian were enrolled in this study. They were clinically examined using standard protocols (5) and pretreatment serum blood samples (Serum-Kabevette, Kabe Labortechnik GmbH, Germany) were obtained from the coccygeal vein.
Additionally, serum blood samples were also taken from control dairy cows (CDC) matched by housing group, lactation number, lactation stage, and gestation stage. Before the tubes were centrifuged $(4 \mathrm{~min}, 3,000 \times \mathrm{g}$ ), samples were allowed to coagulate for $30 \mathrm{~min}$ at $25^{\circ} \mathrm{C}$ in order to extract serum of high quality (17). Serum was subsequently stored at $-20^{\circ} \mathrm{C}$ for a maximum of $14 \mathrm{~d}$ until analysis, as no marked changes in analyte levels are to be expected during short-term storage (4). The clinical chemistry examinations of these samples were performed at $37^{\circ} \mathrm{C}$ with a Cobas $\mathrm{C} 311$ analyser (Roche Diagnostics $\mathrm{GmbH}$, Germany). In total, 32 recumbent and 32 control animals were enrolled in this study. The animals were exposed to the same nutritional and housing conditions as the remaining livestock.

Serum concentrations of different minerals (magnesium, calcium, iron, sodium, potassium, and inorganic phosphorus $\left(\mathrm{P}_{\mathrm{i}}\right)$ ), metabolites ( $\beta$-hydroxybutyrate (BHB), total bilirubin, NEFA, urea, and creatinine), and total protein (TP) were determined. Activities of alkaline phosphatase (AP), aspartate aminotransferase (AST), creatine kinase $(\mathrm{CK})$ and $\gamma$-glutamyl transferase (GGT) were also measured. Table 1 shows the detection methods for each parameter.

Data collection and statistical analysis. For data collection and processing, a standard software package was used (Microsoft Office, Microsoft Corporation, USA). Individual animal data (lactation number, DIM, results of pregnancy check, and days of gestation) were extracted from the herd management software of the farm (HERDE, dsp-Agrosoft, Germany). Clinical chemistry findings, treatment of affected animals, and therapeutic success were also documented.

For statistical data analysis, IBM SPSS Statistics 25 (IBM, USA) and WinSTAT (R. Fitch Software, Germany) software was used. Continuous data comprised count, mean, standard deviation, median, and minimum and maximum, and were checked for normal distribution using histograms and the Shapiro-Wilk test.

Table 1. Detection methods for the serum parameters

\begin{tabular}{ll}
\hline Parameter & Method $^{\text {a }}$ \\
\hline $\mathrm{Mg}, \mathrm{Ca}, \mathrm{P}_{\mathrm{i}}$ & photometric determination \\
$\mathrm{Na}, \mathrm{K}$ & ion-sensitive electrode \\
$\mathrm{Fe}$ & identification with ferrozine (without deproteinisation) \\
$\mathrm{BHB}$ & UV method \\
Bilirubin & according to Jendrassik and Grof (10) \\
NEFA, urea & kinetic UV assay \\
Creatinine & Jaffe reaction \\
AST & optimised standard method of DGKC \\
AP, CK & NAC-activated, optimised standard method of DGKC \\
$\gamma-\mathrm{GT}$ & according to Szasz (29) \\
TP & biuret method \\
\hline
\end{tabular}

DGKC - German Society of Clinical Chemistry and Laboratory Medicine

${ }^{\text {a }}$ performed at $37^{\circ} \mathrm{C}$ with Cobas $\mathrm{C} 311$ analyser, Roche Diagnostics GmbH, Germany

Table 2. Example cross table used for the calculation of odds ratios and McNemar's test

\begin{tabular}{lll}
\hline & \multicolumn{2}{l}{ Above or below reference value } \\
\cline { 2 - 3 } Group & Yes $(\mathrm{n})$ & No $(\mathrm{n})$ \\
\hline RDC & $\mathrm{a}$ & $\mathrm{b}$ \\
CDC & $\mathrm{c}$ & $\mathrm{d}$
\end{tabular}

$\mathrm{OR}=(\mathrm{a} / \mathrm{b}) /(\mathrm{c} / \mathrm{d})$

$=(\mathrm{a} \times \mathrm{d}) /(\mathrm{b} \times \mathrm{c})$

$\mathrm{RDC}$ - recumbent dairy cows; $\mathrm{CDC}$ - control dairy cows; $\mathrm{OR}$ - odds ratio

$\neq$ depending on clinical significance of deflection in recumbent dairy cows 
Table 3. Descriptive statistics of study groups

\begin{tabular}{llll}
\hline \multirow{2}{*}{ Item } & & \multicolumn{2}{c}{ Study groups } \\
\cline { 3 - 4 } & $1(\mathrm{n} / \%)$ & RDC group $(\mathrm{n}=32)$ & $5(15.6)$ \\
\multirow{3}{*}{ Number of lactations } & $2(\mathrm{n} / \%)$ & $7(21.9)$ & $7(21.9)$ \\
& $3(\mathrm{n} / \%)$ & $8(25.0)$ & $8(25.0)$ \\
\hline \multirow{2}{*}{ DIM } & $>3(\mathrm{n} / \%)$ & $12(37.5)$ & $12(37.5)$ \\
\hline Proportion of gravid cows & mean \pm SD & $144 \pm 110$ & $146 \pm 111$ \\
\hline Day of gestation $^{\mathrm{a}}$ & min-max & $7-383$ & $6-384$ \\
\hline
\end{tabular}

RDC - recumbent dairy cows; CDC - control dairy cows; DIM - days in milk

${ }^{a}$ only gravid animals

Table 4. Serum concentrations of examined parameters of the study groups

\begin{tabular}{|c|c|c|c|c|}
\hline & & RDC group $(n=32)$ & CDC group $(n=32)$ & \\
\hline Parameter & Physiological range $^{\mathrm{a}}$ & Mean \pm SD & Mean \pm SD & $\mathrm{P}^{¥}$ \\
\hline $\mathrm{Mg}(\mathrm{mmol} / \mathrm{L})$ & $0.90-1.32$ & $0.94 \pm 0.16$ & $1.03 \pm 0.09$ & 0.008 \\
\hline $\mathrm{Ca}(\mathrm{mmol} / \mathrm{L})$ & $2.00-2.54$ & $2.32 \pm 0.51$ & $2.57 \pm 0.16$ & 0.012 \\
\hline $\mathrm{P}_{\mathrm{i}}(\mathrm{mmol} / \mathrm{L})$ & $1.55-2.29$ & $1.50 \pm 0.61$ & $1.91 \pm 0.24$ & $<0.001$ \\
\hline $\mathrm{Na}(\mathrm{mmol} / \mathrm{L})$ & $135.00-157.00$ & $147.31 \pm 8.21$ & $142.59 \pm 5.71$ & 0.008 \\
\hline $\mathrm{K}(\mathrm{mmol} / \mathrm{L})$ & $3.90-5.20$ & $4.43 \pm 0.75$ & $5.10 \pm 0.77$ & $<0.001$ \\
\hline $\mathrm{Fe}(\mu \mathrm{mol} / \mathrm{L})$ & $13.00-33.00$ & $11.31 \pm 8.15$ & $25.06 \pm 4.48$ & $<0.001$ \\
\hline $\mathrm{BHB}(\mathrm{mmol} / \mathrm{L})$ & $<0.62$ & $0.47 \pm 0.27$ & $0.61 \pm 0.24$ & 0.003 \\
\hline Bilirubin $(\mu \mathrm{mol} / \mathrm{L})$ & $3.30-5.30$ & $4.24 \pm 3.16$ & $1.03 \pm 0.55$ & $<0.001$ \\
\hline NEFA $(\mu \mathrm{mol} / \mathrm{L})$ & $<400.00$ & $509.72 \pm 330.15$ & $136.88 \pm 76.36$ & $<0.001$ \\
\hline Urea $(\mathrm{mmol} / \mathrm{L})$ & $2.00-6.80$ & $5.06 \pm 2.07$ & $3.91 \pm 0.96$ & 0.025 \\
\hline Creatinine $(\mu \mathrm{mol} / \mathrm{L})$ & $50.00-150.00$ & $70.34 \pm 19.67$ & $71.05 \pm 15.90$ & 0.0625 \\
\hline $\mathrm{AP}(\mathrm{U} / \mathrm{L})$ & $40.00-300.00$ & $54.19 \pm 24.96$ & $45.94 \pm 13.98$ & 0.062 \\
\hline CK (U/L) & $<150.00$ & $5011.28 \pm 13386.53$ & $666.44 \pm 1645.44$ & $<0.001$ \\
\hline $\operatorname{AST}(\mathrm{U} / \mathrm{L})$ & $<80.00$ & $231.07 \pm 207.75$ & $92.32 \pm 14.96$ & 0.020 \\
\hline GGT (U/L) & $<50.00$ & $36.43 \pm 20.45$ & $31.14 \pm 12.36$ & 0.0625 \\
\hline $\mathrm{TP}(\mathrm{g} / \mathrm{L})$ & $68.00-82.00$ & $84.36 \pm 8.01$ & $80.72 \pm 6.04$ & 0.029 \\
\hline
\end{tabular}

$\mathrm{RDC}$ - recumbent dairy cows; $\mathrm{CDC}$ - control dairy cows

${ }^{a}$ according to Fürll (9) and Van Winden et al. (31)

¥ Student's $t$-test for dependent samples

Table 5. Odds ratios for exceedance or lower deviation of serum parameter threshold values of the experimental group

\begin{tabular}{|c|c|c|c|c|}
\hline & & RDC group & & \\
\hline Parameter deviation & $\begin{array}{l}\text { Physiological threshold } \\
\text { value }^{\mathrm{a}}\end{array}$ & OR & $95 \% \mathrm{CI}$ & $\mathrm{P}^{¥}$ \\
\hline $\mathrm{Mg} \downarrow$ & $<0.90 \mathrm{mmol} / \mathrm{L}$ & 3.667 & $1.023-13.143$ & 0.092 \\
\hline $\mathrm{Ca} \downarrow$ & $<2.00 \mathrm{mmol} / \mathrm{L}$ & 4.429 & $0.467-42.021$ & 0.250 \\
\hline $\mathrm{P}_{\mathrm{i}} \downarrow$ & $<1.55 \mathrm{mmol} / \mathrm{L}$ & $\mathrm{x}$ & & \\
\hline $\mathrm{Na} \downarrow$ & $<135.00 \mathrm{mmol} / \mathrm{L}$ & 0.484 & $0.042-5.621$ & 1.000 \\
\hline$K \downarrow$ & $<3.90 \mathrm{mmol} / \mathrm{L}$ & $\mathrm{x}$ & & \\
\hline $\mathrm{Fe} \downarrow$ & $<13.00 \mu \mathrm{mol} / \mathrm{L}$ & $\mathrm{x}$ & & \\
\hline $\mathrm{BHB} \uparrow$ & $>0.62 \mathrm{mmol} / \mathrm{L}$ & 0.407 & $0.121-1.369$ & 0.227 \\
\hline Bilirubin $\uparrow$ & $>5.30 \mu \mathrm{mol} / \mathrm{L}$ & $\mathrm{x}$ & & \\
\hline NEFA $\uparrow$ & $>400.00 \mu \mathrm{mol} / \mathrm{L}$ & $\mathrm{x}$ & & \\
\hline Urea $\uparrow$ & $>2.00 \mathrm{mmol} / \mathrm{L}$ & $\mathrm{x}$ & & \\
\hline Creatinine $\uparrow$ & $>150.00 \mu \mathrm{mol} / \mathrm{L}$ & $\mathrm{xx}$ & & \\
\hline $\mathrm{AP} \downarrow$ & $<40.00 \mathrm{U} / \mathrm{L}$ & 0.866 & $0.302-2.481$ & 1.000 \\
\hline $\mathrm{CK} \uparrow$ & $>150.00 \mathrm{U} / \mathrm{L}$ & 23.059 & $2.778-191.410$ & $<0.001$ \\
\hline $\operatorname{AST} \uparrow$ & $>80.00 \mathrm{U} / \mathrm{L}$ & 5.357 & $0.555-51.709$ & 1.000 \\
\hline GGT $\uparrow$ & $>50.00 \mathrm{U} / \mathrm{L}$ & 1.554 & $0.241-10.010$ & 1.000 \\
\hline $\mathrm{TP} \uparrow$ & $>82.00 \mathrm{~g} / \mathrm{L}$ & 2.341 & $0.843-6.353$ & 0.210 \\
\hline
\end{tabular}

RDC - recumbent dairy cows; OR - odds ratio; $\mathrm{CI}$ - confidence interval; $\mathrm{x}$ - reference value was not exceeded but was attained in healthy cows; $\mathrm{xx}$ - reference value was exceeded in none of the study groups

a according to Fürll (9) and Van Winden et al. (31)

$¥$ McNemar’s test 
(A)

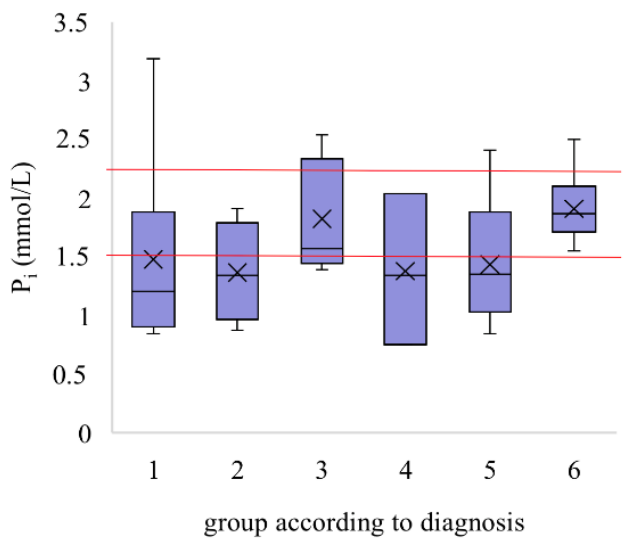

(C)

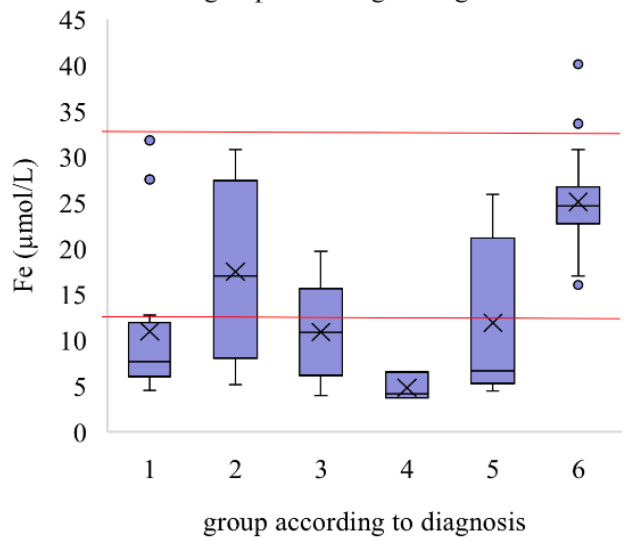

(E)

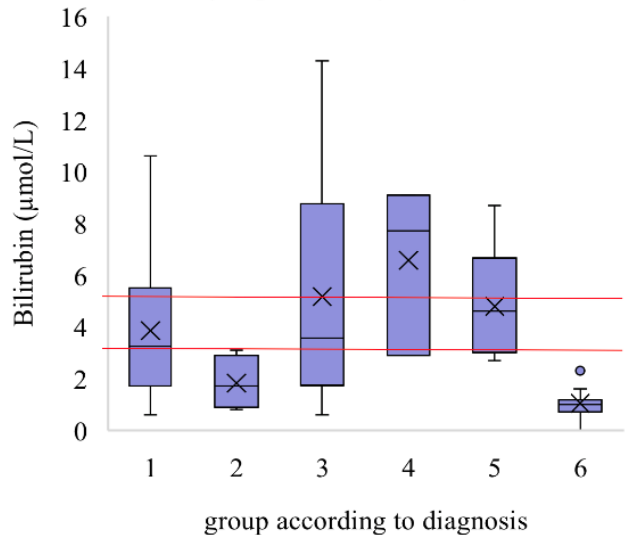

(G) 80000

70000

60000

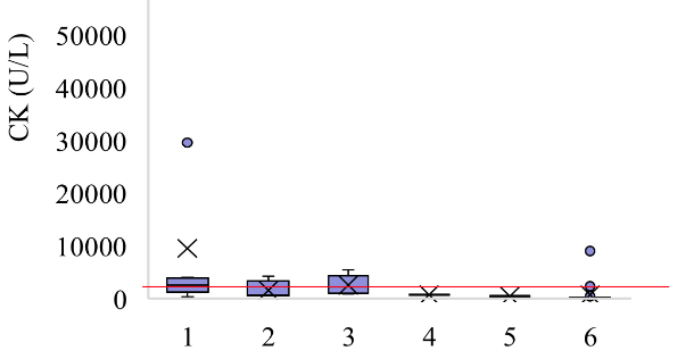

group according to diagnosis
(B)

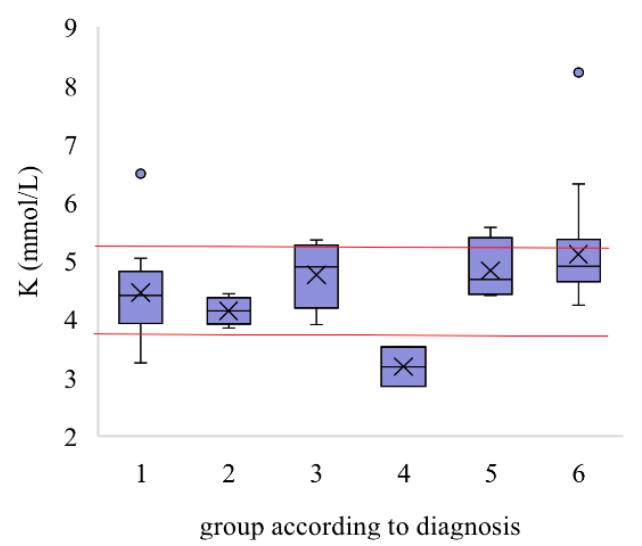

(D)

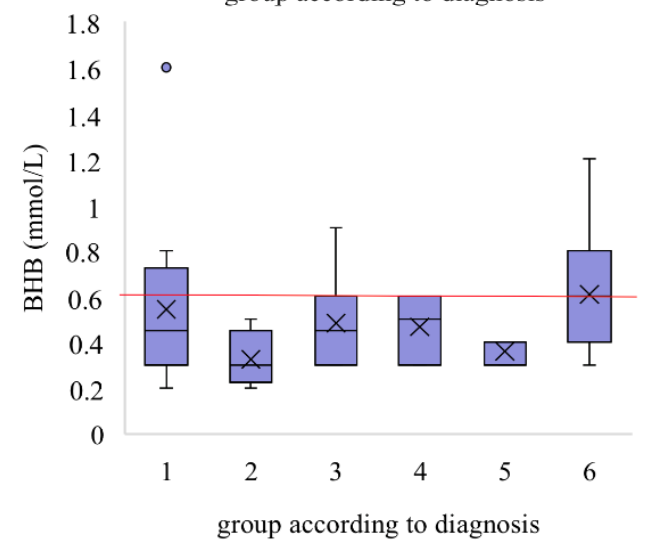

(F)

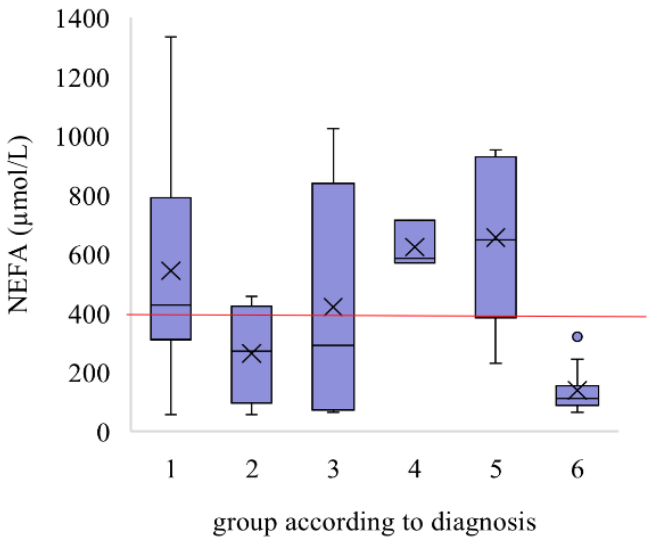

Fig. 1. Box-and-whisker plots illustrating serum concentrations in diagnosis groups ( 1 - adductor muscle injury, 2 - fractures, 3 - other mechanical traumatic lesions of locomotor system, 4 - coliform mastitis, 5 - miscellaneous (ruminal tympany, cachexia, spinal abscess, tarsitis), 6 - healthy control animals). A - phosphorus, $\mathrm{B}$ - potassium, $\mathrm{C}$ - iron, $\mathrm{D}-\beta$-hydroxybutyrate, $\mathrm{E}$ - total bilirubin, $\mathrm{F}-$ non-esterified fatty acids, and $\mathrm{G}-$ creatine kinase. Parameters returning means differing significantly between the RCD and CDC groups were chosen for these plots (Table 4). Descriptive differences between the diagnosis groups could not be proven to be statistically significant (P $>0.003$ ). Group 6 (healthy control cows) was not included in the ANOVA for independent samples due to the dependent data structure of ANOVA (matched pairs of a recumbent dairy cow and a control dairy cow). Red horizontal lines - upper and lower limits of the reference ranges according to Fürll (9) and Van Winden et al. (31); horizontal lines within the boxes - medians; crosses within the boxes - means 
If necessary, data were transformed logarithmically (decadic logarithm) to gain normality. Homogeneity of variances was investigated by the Levene test (27).

In the first step, clinical chemistry values of RDC and CDC were compared by Student's $t$-test for dependent samples as recommended for matched pairs (6). Each cow from the RDC group was matched with one cow of the CDC group as described in the section titled "Study design and case definitions".

Subsequently, the numbers of animals exceeding or falling short of the reference ranges were compared between the groups using cross tabulations and McNemar's test. The odds ratios (OR) were calculated as described in Table 2 (25).

Finally, animals within the RDC group were classified according to diagnosis (1 - adductor muscle injury, 2 - fractures, 3 - other mechanical traumatic lesions of locomotor system, 4 - coliform mastitis, and 5 - miscellaneous (ruminal tympany, cachexia, spinal abscess, tarsitis)). The means of clinical chemistry parameters were compared by using a univariate analysis of variance (ANOVA) for independent samples. Post-hoc pairwise comparison was performed by a Games-Howell test (6).

\section{Results}

Data were analysed from 64 animals enrolled in this trial. Descriptive statistics of the RDC and CDC groups regarding lactation number, DIM, proportion of gravid cows, as well as day of gestation are presented in Table 3.

A comparison of mean blood serum concentrations between RDC and CDC is shown in Table 4. All mean serum concentrations of minerals except $\mathrm{Na}$ were decreased in RDC, whereas $\mathrm{K}$ and $\mathrm{P}_{\mathrm{i}}$ as well as $\mathrm{Fe}$ concentrations in RDC were significantly lower than those in the healthy group. However, we could find hypocalcaemia in three cows of the RDC group (mmol/L: $0.85 ; 1.70$; and 0.97 ). RDC had significantly higher concentrations of NEFA and bilirubin compared to $\mathrm{CDC}$, while other blood metabolic markers (creatinine, urea) did not differ statistically. Regarding enzymes, in RDC increased AP, AST, CK, and GGT activities were detected, although only $\mathrm{CK}$ concentration was significantly different between the two groups. In addition, the mean concentration of BHB was lower and serum TP was non-significantly higher in recumbent than in healthy cows.

OR for exceedance or lower deviation of different parameter threshold values are displayed in Table 5. Significantly more recumbent cows exceeded the upper reference value compared to the CDC group only with regard to $\mathrm{CK}$ activity.

When comparing results for blood analysis between the diagnoses within the RDC group, some descriptive differences could be detected (Fig. 1), but they were proven not to be statistically significant. Serum urea concentration was higher in cows suffering from coliform mastitis (group 4), while AST and CK were increased in animals with adductor muscle rupture, in which CK activity reached values above $68,000 \mathrm{U} / \mathrm{L}$, as well as mechanical traumatic lesions of the locomotor system (groups 1 and 3). Cows with adductor muscle injury (group 1) had increased bilirubin as well as NEFA values, and those suffering from coliform mastitis (group 4) also showed an increase in NEFA in their blood. In respect of minerals, Fe was depleted in cases of adductor muscle lesion and coliform mastitis (groups 1 and 4) and there was hypokalaemia in cases of fractures and coliform mastitis (groups 2 and 4). Moreover, adductor muscle injury (group 1) caused lower $P_{i}$ values. Serum concentrations of selected parameters within the diagnosis groups are displayed in Fig. 1, for which parameters returning means differing significantly between the RCD and CDC groups were chosen for plotting (Table 4).

\section{Discussion}

The main aim of this study was to check the clinical background of blood serum parameter changes in recumbent lactating German Holstein cows outside the risk period for hypocalcaemic parturient paresis in comparison with parameters of healthy control cows. Mean serum concentrations and activities of NEFA, bilirubin, and CK were statistically higher in RDC than in healthy cows, while RDC showed significantly lower concentrations of $\mathrm{Fe}, \mathrm{K}, \mathrm{P}_{\mathrm{i}}$, and $\mathrm{BHB}$ compared to CDC. Significant differences regarding other parameters were not observed.

The degree of mineral deficiencies in RDC was pronounced in the present study, as animals were sampled before the first treatment (e.g. administration of sodium bicarbonate or dexamethasone) rather than after it as is the procedure in most field trials. As a result, potential differences from the CDC group can be imperfectly representative in such studies.

Ca homeostasis is stable for more than $3 \mathrm{~d}$ postpartum and thus, primary hypocalcaemia in recumbent dairy cows should be insignificant after this period. Serum Ca concentrations of three cows observed in the RDC group show the presence of subclinical $(1.40-2.00 \mathrm{mmol} / \mathrm{L})$ and clinical $(<1.40 \mathrm{mmol} / \mathrm{L})$ hypocalcaemia after the periparturient period (19). The Ca threshold value of $2.00 \mathrm{mmol} / \mathrm{L}$ was selected to exclude cows with a decreased serum concentration that is normal in the periparturient period (21). Besides being regulated by 1,25-dihydroxyvitamin $\mathrm{D}$, blood $\mathrm{Ca}$ is also regulated by parathyroid hormone (PTH) controlling bone $\mathrm{Ca}$ mobilisation as well as renal and intestinal $\mathrm{Ca}$ reabsorption $(14,18)$. Both metabolic alkalosis and hypomagnesaemia are able to impair PTH receptor function. At higher $\mathrm{pH}$ values as a consequence of a diet that supplies more cations, the receptor protein may alter its conformation, rendering the tissues less sensitive to 
PTH. $\mathrm{Mg}$ as a ligand of adenylate cyclase and phospholipase $\mathrm{C}$ plays a key role in second messenger cascades after PTH has bound to its receptor and is crucial for their full activity. Maintenance of physiological blood $\mathrm{Mg}$ concentration is almost exclusively dependent on a constant influx from nutrition. Thus, partial or total anorexia in the cow is frequently accompanied by lower blood $\mathrm{Mg}$ values. Clinical signs of hypomagnesaemia such as recumbency combined with convulsions are only seen if blood $\mathrm{Mg}$ falls below $0.5 \mathrm{mmol} / \mathrm{L}(13,20,22)$. The hypocalcaemia observed in the cows of this study most likely arose secondarily, due to a lower feed intake as the reason for hypomagnesaemia, and this can usually be cured by an intravenous $\mathrm{Ca}$ infusion. Despite $\mathrm{Mg}$ or $\mathrm{Ca}$ deficiencies being impossible to allocate to certain diagnoses within the RDC group and seeming not to be the main cause of recumbency in this study, hypocalcaemia merits consideration as a possible cause of recumbency in later lactation. Therefore, attention should be focused on sufficient supply of $\mathrm{Mg}$.

It should be noted that hypocalcaemic cows tend to become hypophosphataemic, because PTH, secreted in response to low blood $\mathrm{Ca}$, increases urinary and salivary loss of $\mathrm{P}_{\mathrm{i}}$ (14). Otherwise, foetal $\mathrm{P}_{\mathrm{i}}$ demand (especially in twin pregnancies) in late gestation, decreased absorption of salivary $\mathrm{P}_{\mathrm{i}}$ due to reduced ruminal motility, an elevated tumour necrosis factor (TNF)- $\alpha$ level, and excessive cortisol secretion can induce hypophosphataemia $(2,14)$. This might explain the $P_{i}$ concentrations detected in the RDC group, since it included heavily pregnant cows possibly secreting more cortisol and digesting less by reason of their impaired welfare as recumbent animals.

If recumbent cows are normocalcaemic or are not able to rise $24-48 \mathrm{~h}$ after Ca treatment, this condition is termed downer cow syndrome (DCS). Its development varies (13). In the following, various disorders which were detected in this study and which may cause DCS are discussed.

Hypokalaemia observed in RDC in our study can occasionally co-occur with muscle weakness and recumbency. Most cases occur secondarily due to prolonged inappetence, diarrhoea, or gastrointestinal passage disorders; however, this hypokalaemia is unlikely to be severe enough to cause clinical signs of weakness. Renal $\mathrm{K}$ excretion is regulated by aldosterone, which is in turn controlled by adrenocorticotropic hormone (ACTH). Aldosterone enhances secretion of $\mathrm{K}$ and causes retention of $\mathrm{Na}$. Hypovolaemia and low plasma $\mathrm{Na}$ are the most important triggers for its secretion. This might be the reason for the more frequent $\mathrm{K}$ loss in cows with fractures as they usually develop circulatory insufficiency. If glucocorticoids, which are sometimes administered to cows as antiphlogistics or to stimulate gluconeogenesis, also have some mineralocorticoid effects they will lead to hypokalaemia by increasing $\mathrm{K}$ excretion in the kidneys $(14,23)$. Previous treatments of the glucocorticoid kind could be ruled out in the present study. Another important point is that there can be disturbances of the hypothalamic-pituitary-adrenal axis and therefore changes in plasma electrolytes during sepsis or endotoxin exposure. While ACTH concentrations were found to be reduced after experimentally induced sepsis in rats, aldosterone was continuously elevated, resulting in a significant $\mathrm{K}$ reduction (7). This could be an explanation for the higher occurrence of hypokalaemia in cattle suffering from coliform mastitis, as this disease commonly induces endotoxaemia in these animals.

The majority of blood Fe is bound to transferrin, a negative acute phase protein in cattle. While animals with acute infections have normal transferrin concentrations, chronic infectious diseases were characterised by relatively low transferrin values, which may also induce low Fe concentrations (30). This observation could not be shown in our study, since low serum $\mathrm{Fe}$ values were associated with adductor muscle injury and coliform mastitis as diseases of primarily acute character. However, evidence suggests that transport capacity for Fe is reduced in recumbent cows during their acute phase reaction (19). Deficiency of Fe due to continuing inappetence is additionally possible in the present cases. In the same way as for $\mathrm{K}$ and $\mathrm{P}_{\mathrm{i}}$ deficiency, cows will rapidly restore blood Fe to normal levels if they are consuming feed. Therefore, in tending these animals, treatment should be given for any concomitant or pre-existing problems (23).

Hyperbilirubinaemia detected in RDC results secondarily from elevated NEFA concentrations because NEFA occupy the binding site of transport proteins for bilirubin. In these cows, lipomobilisation is most likely initiated by anorexia (inanition icterus), increased stress caused by the recumbent position, and the inhibiting effects of TNF- $\alpha$ secreted in inflammatory processes on insulin-mediated reduction of lipolysis $(8,15)$. Concentrations of BHB were within the physiological range for the large part of the RDC group, indicating that these cows did not show subclinical or clinical ketosis. This suggests that ketosis was not important for recumbency in this study.

Prerenal uraemia caused by hypovolaemia and circulatory insufficiency might explain the higher urea concentrations of cows suffering from coliform mastitis within the RDC group. This is consistent with the observation that the endotoxin from $E$. coli can disrupt the blood flow and is therefore able to cause systemic signs of disease like diarrhoea and dehydration (16).

Levels of CK are known to rise 12-24 h after the start of recumbency and can be subject to large fluctuations beforehand $(3,26)$. Mean CK activity was high in RDC, as expected in our study. The reason for this is affected animals' long-lasting inability to rise. High CK and AST values are associated with a poor prognosis in recumbent cattle (26). Due to low statistical power, conclusions about cure rates of RDC cannot be drawn in the present work (data not shown). In contrast 
to the case with $\mathrm{CK}$, the significant rise in the AST activity in cows with muscle injury could be explained by a slower increase and longer half-life of AST after trauma than of $\mathrm{CK}$, reaching maximum concentration in blood after 36-48 h (24).

Other diagnostic measures such as determination of acute phase proteins (haptoglobin and serum amyloid A) or cerebrospinal fluid analysis to identify central nervous system lesions could have helped to find further correlations between RDC and healthy cows $(1,30)$. It would also have been desirable to include a larger number of cattle in the two groups. However, the comparison of $\mathrm{RDC}$ and $\mathrm{CDC}$ exposed to equal nutritional and housing conditions should be of interest.

In conclusion, the present study provides information about the clinical background as well as blood serum concentrations of different clinical chemistry parameters in recumbent and healthy lactating dairy cattle outside the risk period for hypocalcaemic paresis. Recumbency $>5$ DIM has mainly traumatic and inflammatory causes and we could only show additional diagnostic (e.g. occurrence of hypocalcaemia at later lactation stages) as well as therapeutic (e.g. in the case of hypokalaemia in regards to septicaemic processes) value for a limited number of parameters. Therefore, only the examination of parameters restricted to a selected range can be recommended, including some minerals $\left(\mathrm{K}, \mathrm{P}_{\mathrm{i}}\right.$, and $\mathrm{Fe}$ ), metabolites (NEFA and bilirubin), and $\mathrm{CK}$ based on their significant differences between RDC and CDC. They can furthermore help to confine various differential diagnoses in recumbent dairy cattle. This would be useful in cows when the clinical examination fails to provide sufficient diagnostic information or when there is a suspicion of septicaemia in individual animals and alkalosis or hypomagnesaemia in the herd. Further studies preferably with a larger number of enrolled animals are necessary to confirm the results presented here. The diagnostic and prognostic value of further parameters (e.g. acute phase proteins) should be additionally elucidated.

Conflict of Interests Statement: The authors declare that there is no conflict of interests regarding the publication of this article.

Financial Disclosure Statement: Clinical chemistry investigations were funded by the Faculty of Veterinary Medicine, University of Leipzig, Germany. The farm bore the costs for clinical examination of animals and blood sample collection.

Animal Rights Statement: Blood samples were drawn by the herd veterinarian as part of routine diagnostic procedures (metabolic and epidemiological testing) with informed owner consent. Therefore, the study was exempt from ethical approval according to the German regulations.
* Jim Weber and Markus Zenker contributed equally to this study.

\section{References}

1. Achard D., Francoz D., Grimes C., Desrochers A., Nichols S., Babkine M., Fecteau G.: Cerebrospinal fluid analysis in recumbent adult dairy cows with or without spinal cord lesions. J Vet Intern Med 2017, 31, 940-945.

2. Chen H., Xu H., Dong J., Li J., Ghishan F.K.: Tumor necrosis factor-alpha impairs intestinal phosphate absorption in colitis. Am J Physiol Gastrointest Liver Physiol 2009, 296, 775-781.

3. Cox V.S., McGrath J.C., Jorgensen S.E.: The role of pressure damage in pathogenesis of the downer cow syndrome. Am J Vet Res 1982, 43, 26-31.

4. Cray C., Rodriguez M., Zaias J., Altman N.H.: Effects of storage temperature and time on clinical biochemical parameters from rat serum. J Am Assoc Lab Anim Sci 2009, 48, 202-204.

5. Dirksen G.: Untersuchung festliegender Rinder (Investigation of recumbent cattle). In: Die klinische Untersuchung des Rindes, edited by G. Dirksen, H.D. Gründer, M. Stöber, Parey Verlag, Berlin, 1990, pp. 585-588.

6. du Prel J.B., Röhrig B., Hommel G., Blettner M.: Choosing statistical tests - Part 12 of a series on evaluation of scientific publications. Dtsch Arztebl Int 2010, 107, 343-348.

7. Flierl M.A., Rittirsch D., Weckbach S., Huber-Lang M., Ipaktchi K., Ward P.A., Stahel P.F.: Disturbances of the hypothalamicpituitary-adrenal axis and plasma electrolytes during experimental sepsis. Ann Intensive Care 2011, 1, 53-53.

8. Fürll M.: Stoffwechselüberwachung bei Rindern (Monitoring of cattle for metabolic imbalances). In: Klinische Labordiagnostik in der Tiermedizin, edited by A. Moritz, Schattauer Verlag, Berlin, 2013, pp. 748-777.

9. Fürll M., Schäfer M.: Lipolyse und Hyperbilirubinämie - Beitrag zur Pathogenese des Ikterus (The role of lipolysis and hyperbilirubinaemia in pathogenesis of icterus). Monatsh Veterinarmed 1992, 47, 181-185.

10. Garber C.C.: Jendrassik-Grof analysis for total and direct bilirubin in serum with a centrifugal analyzer. Clin Chem 1981, 27, 1410-1416.

11. Gelfert C.C., Alpers I., Dallmeyer M., Decker M., Hüting A., Lesch S., Baumgartner W., Staufenbiel R.: Factors affecting the success rate of treatment of recumbent dairy cows suffering from hypocalcaemia. J Vet Med A Physiol Pathol Clin Med 2007, 54, 191-198.

12. GfE - Society of Nutrition Physiology: Recommendations of energy and nutrient supply of dairy and young cattle. DLGVerlags, Frankfurt, 2001.

13. Goff J.P.: Macromineral physiology and application to the feeding of the dairy cow for prevention of milk fever and other periparturient mineral disorders. Anim Feed Sci Technol 2006, $126,237-257$.

14. Goff J.P., Horst R.L., Mueller F.J., Miller J.K., Kiess G.A., Dowlen H.H.: Addition of chloride to a prepartal diet high in cations increases 1,25-dihydroxyvitamin $\mathrm{D}$ response to hypocalcemia preventing milk fever. J Dairy Sci 1991, 74, 3863-3871.

15. Heilig M., Bäuml D., Fürll M.: Bedeutung der Spurenelemente Zink und Eisen bei der Gebärparese des Rindes (The relevance of the trace elements zinc and iron in the milk fever disease of cattle). Tierarztl Prax G 2014, 42, 199-208.

16. Hogan J., Smith K.L.: Coliform mastitis. Vet Res 2003, 34, 507-519.

17. Magee L.S.: Lab Notes. BD Diagnostics-Preanalytical Systems 2005, 15, 1-4.

18. Martín-Tereso J., Martens H.: Calcium and magnesium physiology and nutrition in relation to the prevention of milk fever and tetany (dietary management of macrominerals in preventing disease). Vet Clin North Am Food Anim Pract 2014, 30, 643-670. 
19. Moser M., Pfister H., Bruckmaier R.M., Rehage J., Blum J.W.: Blood serum transferrin concentration in cattle in various physiological states, in veal calves fed different amounts of iron, and in cattle affected by infectious and non-infectious diseases. Zentralbl Veterinarmed A 1994, 41, 413-420.

20. Phillippo M., Reid G.W., Nevison I.M.: Parturient hypocalcaemia in dairy cows: effects of dietary acidity on plasma minerals and calciotrophic hormones. Res Vet Sci 1994, 56, 303-309.

21. Roche J., Berry D.: Periparturient climatic, animal, and management factors influencing the incidence of milk fever in grazing systems. J Dairy Sci 2006, 89, 2775-2783.

22. Rude R.K., Oldham S.B., Sharp Jr C.F., Singer F.R.: Parathyroid hormone secretion in magnesium deficiency. J Clin Endocrinol Metab 1978, 47, 800-806.

23. Sattler N., Fecteau G.: Hypokalemia syndrome in cattle. Vet Clin North Am Food Anim Pract 2014, 30, 351-557.

24. Sattler T., Fürll M.: Creatine kinase and aspartate aminotransferase in cows as indicators for endometritis. J Vet Med A Physiol Pathol Clin Med 2004, 51, 132-137.

25. Sauerbrei W., Blettner M.: Interpreting results in $2 \times 2$ Tables: Extensions and problems - Part 9 of a series on evaluation of scientific publications. Dtsch Arztebl Int 2009, 106, 795-800.

26. Shpigel N.Y., Avidar Y., Bogin E.: Value of measurements of the serum activities of creatine phosphokinase, aspartate aminotransferase and lactate dehydrogenase for predicting whether recumbent dairy cows will recover. Vet Rec 2003, 152, 773-776.

27. Spriestersbach A., Röhrig B., du Prel J.B., Gerhold-Ay A., Blettner M.: Descriptive Statistics: The specification of statistical measures and their presentation in tables and graphs - Part 7 of a series on evaluation of scientific publications. Dtsch Arztebl Int 2009, 106, 578-583.

28. Stolla R., Schulz H., Martin R.: Veränderungen im Krankheitsbild des peripartalen Festliegens beim Rind (Changes in the clinical appearance of periparturient recumbency in cattle). Tierarztl Umsch 2000, 55, 295-299.

29. Szasz G.: A kinetic photometric method for serum gammaglutamyl transpeptidase. Clin Chem 1969, 15, 124-136.

30. Tothova C., Nagy O., Kovac G.: Acute phase proteins and their use in the diagnosis of diseases in ruminants: a review. Vet Med (Prague) 2014, 59, 163-180

31. Van Winden S.C., Jorritsma R., Müller K.E., Noordhuizen J.P.: Feed intake, milk yield and metabolic parameters prior to left displaced abomasums in dairy cows. J Dairy Sci 2003, 86, 1465-1471.

32. Victor A., Elsäßer A., Hommel G., Blettner M.: Judging a plethora of p-values: How to contend with the problem of multiple testing - Part 10 of a series on evaluation of scientific publications. Dtsch Arztebl Int 2010, 107, 50-56. 